\title{
Soft Tissue Biology and Management in Implant Dentistry
}

\author{
Yeung Stephen C H \\ Faculty of Dentistry, University of Sydney, Sydeny, \\ Westmead Centre for Oral Health, Westmead Hospital, Westmead, \\ Australia
}

\section{Introduction}

Implant Dentistry has been the fastest growing treatment modality in dentistry for the past 20 years. The success in using dental implant to support dental restorations and reconstructions has been underpinned by the predictable formation of a bone-to-titanium interface (osseointegration) after the insertion of a titanium implant into the human jaw bone. As a result, the titanium implant becomes a rigid extension of the jaw and can be utilised as a stable foundation to support dental restorations and enable normal function of mastication to be carried out by the patient in comfort over long periods of time. The longevity of the dental implant treatment is therefore dependent upon the stability of the bone-to-implant interface. This interface is a dynamic situation subject to the influence of bone metabolism and turnover as well as bone remodelling according to functional demand. It is therefore reasonable to assume that successful implant treatment and implant supported prostheses can be maintained over long periods of time in the absence of bone metabolic diseases or disturbance.

The reporting of peri-implantitis as a significant threat to implant survival in the jaw bone (Roos Jansåker, Lindahl et al. 2006; Lindhe and Meyle 2008) has dramatically changed our perception of the expected trouble-free service life of dental implants in patients, particularly in those who have had a history of periodontal disease in the past. It also brought into focus a number of known risk factors associated with the bacteria-related breakdown of osseointegration and raised concerns about how best to address these risks. It is now apparent that maintaining a competent seal of the "gingival cuff" surrounding dental implants or abutments has an important role to play in achieving long term complicationfree service of dental implant restorations/reconstructions(Berglundh, Lindhe et al. 1991). This Chapter will review all relevant biological and clinical aspects of our current knowledge of the peri-implant gingival tissue and the management of this tissue to achieve long term clinical success of implant treatment.

In the anterior aesthetic zone, the restorative dentist is often faced with a challenge to restore not only the missing teeth but also the missing volume of gingival tissue surrounding them. In augmented implant sites, the recreated volume of gingival tissue must have a healthy appearance and be in harmony with the gingival tissue surrounding adjacent teeth. Furthermore, this tissue should be stable and remain unchanged in volume and appearance over time. This demand in aesthetic outcome for dental treatment in the anterior region is 
often at odds with the known biological events in soft tissue healing and remodelling after surgical wounding. In clinical practice, it is therefore critically important for the dentist to understand all the biological events associated with wound healing and to have the knowledge and skill to perform procedures of augmentation that are evidence based. Equally important, the patient should be encouraged to have only "realistic" expectation in terms of aesthetic outcome in any dental reconstruction in the anterior region. This Chapter will also review some surgical procedures that had been shown to yield reliable results.

\section{Biological basis for soft tissue healing around dental implants}

\subsection{Gingival shrinkage around dental implants}

During the healing phase following implant placement surgery (stage 1 surgery) or the trans-mucosal surgery for abutment connection (stage 2 surgery), the soft tissue re-organises itself according to the new environment (namely, surrounding a metallic implant). Noting the histologic observation made by Berglundh (Berglundh, Lindhe et al. 1991)and other investigator groups (regarding the orientation of the collagen fibre groups in the periimplant gingival tissue) it is easy to appreciate why the peri-implant gingival tissue appears to shrink during the early stage of wound healing. The longitudinal arrangement of the major collagen fibre groups amplifes the process of collagen fibril contraction (as part of collagen maturation) in the vertical direction. Clinically, this process is observed as marginal gingiva shrinkage. In the anterior aesthetic zone, the amount of gingival shrinkage can be crucial to the success or failure of a case. Therefore when planning such a case, it is important to take into account the position and structural integrity of the labial bone wall which forms form the support base for the labial gingiva.

\subsection{Peri-implant soft tissue seal}

In a dog study(Berglundh, Lindhe et al. 1991), Berglundh and co-workers compared the similarities in the peri-implant soft tissue to that of the gingival tissue around teeth. In both cases, the soft tissue consisted of a junctional epithelium component and a connective tissue component. In both situations, the epithelium adhered to the tooth or titanium surface in similar fashion. However, in the connective tissue compartment there were notable differences. The peri-implant tissue had a higher fibre content (and hence a lower cellular content) than that of gingiva around teeth. In addition, the collagen fibres were arranged parallel to the titanium surface(Çomut, Weber et al. 2001) in contrast to that of the gingiva which tended to be arranged perpendicular to the cementum surface of the tooth root with other fibre groups arranged in various patterns elsewhere in the marginal gingiva. Some of these fibres had previously been observed to be inserted and embedded into the cementum layer forming Sharpey's fibers(Garant and Cho 1979). Because the study animals were subjected to plaque control regime for 8 weeks prior to sacrifice, there was little or no inflammatory cell infiltrates observed in either the gingiva or peri-implant tissues. The authors thus concluded that a satisfactory seal had been formed around the implant/abutment and that this seal was capable of maintaining tissue health (provided plaque control is practiced).

Since the time when the Berglundh's group described the pattern of collagen fibre bundles running parallel along the titanium surface (Berglundh, Lindhe et al. 1991), others had reported various fibre bundles organized in different fashions either obliquely to the titanium surface or circumferential to it(Buser, Weber et al. 1992; Ruggeri, Franchi et al. 
1994; Piattelli, Scarano et al. 1997; Çomut, Weber et al. 2001; Schupbach and Glauser 2007). The precise significance of these observations was unclear. There were speculations that these fibre groups fulfil structural support and defensive role of the peri-implant soft tissue. In one recent report, controversial claims were made that "functionally" oriented fibre bundles were found lying perpendicular to the TiUnite surface of Branemark implants(Rocci, Martignoni et al. 2003). The significance of this finding was also not clear as no follow up study was done. Nevertheless, implants with roughened surface (up to the collar) are now available for clinical use, on the basis that such implant design could enable faster osseointegration and allow the formation of a durable soft-tissue cuff even on roughened titanium surface. This concept has not received general support among dental practitioners partly because of the lack of good clinical data to support its use, and partly because of concern about the potential for accelerated loss of osseointegration should this roughened surface becomes uncovered and exposed to the oral environment(Cosyn, Sabzevar et al. 2007).

This anatomical feature of soft tissue around titanium implant was found to be consistent for titanium surfaces irrespective of the type of implant system used(Abrahamsson, Berglundh et al. 1996). Furthermore, the surface roughness of the titanium had no bearing on the adherence of the soft tissue(Abrahamsson, Zitzmann et al. 2002). Neither was the clinical protocol used in implant placement (one-stage as versus 2 stages protocol)(Abrahamsson, Berglundh et al. 1999). Despite these observations, the clinical performance of this seal in protecting against bacterial ingression and thus peri-implant infection remained untested. Indirect evidence from human clinical studies which generally reported very low incidence of peri-implantitis and peri-implant mucositis suggested that indeed, the soft tissue cuff around titanium implant/abutment could provide comparable protection as gingiva around teeth. The importance of this physical seal notwithstanding, for long term peri-implant health, the presence of bacteria, bacterial plaque and biofilm will also need to be kept at a minimum. It is therefore crucial that restorations supported by implants should have built-in access channels or space for hygiene practice, and the patient should be educated in an effective method of plaque control. The failure to do so are seen too frequently as heavy plaque and calculus buildup around dental constructions as well as abutment or even implant surfaces when significant gingival recession has uncovered these implant components.

\subsection{The keratinized gingival zone}

The controversy about the need for a keratinized (attached) gingival zone around implant supported restorations is an interesting one. Based on the data from long term implant success and implant survival studies, there appeared to be little or no difference in the success rate for implants to be placed in oral mucosa zone or keratinized gingival zone(Jemt, Chai et al. ; Brånemark, Svensson et al. 1995; Lindquist, Carlsson et al. 1996; Buser, Mericske stern et al. 1997; Mericske-Stern 1998). It was therefore argued that there was no convincing evidence to support the clinical obsession of placing dental implants in keratinized gingival zone only or to re-create this soft tissue band after implant placement(Carmichael, Apse et al. 1989). In a recent systemic review, Esposito and colleagues concluded that there was insufficient evidence to suggest any surgical technique or approach was superior to another although they did note that flapless approach tended to result in less post-operative discomfort and pain. They also found no case to recommend that increasing the "keratinized tissue" band around dental implants as a preferred method of tissue management(Esposito, Murray-Curtis et al. 2007). Nevertheless, the common clinical 
observation of frequent plaque accumulation associated with mobile mucosal tissue around implant restorations and the subsequent soft tissue inflammation (and hence patient complaints) often lead to the demand for clinical intervention (figure 1). Clearly, the amount of peri-implant mucosal tissue movement during function is influenced by a number of physical variables and is difficult to measure. Until there is a reliable and accurate way of clinically assessing soft tissue movement during function, for many clinicians there is a case for routinely providing a keratinized gingival band around implant restorations in order to facilitate plaque control and hence reduce the incidence of plaque-related peri-implant disease. In a recent publication in the International Journal of Oral \& Maxillofacial Implants, in a Current Issues Forum, the editor posted the question "To minimize complications, is it essential that implant abutments be surrounded by keratinized tissue?"(Krygier, Glick et al.). The consensus of opinions expressed by the authors participating in this debate was in general, supportive of the clinical practice of providing a keratinized gingival band around implant restorations where possible and practical. Another recent study reported a 5-year observation provided further data to support that keratinized gingival band of $>2 \mathrm{~mm}$ promotes better gingival health around dental implant/restorations(Schrott, Jimenez et al. 2009). In a systemic review, Cairo and others concluded that in some clinical situations soft tissue augmentation is warranted(Cairo, Pagliaro et al. 2008). A more recent review also concluded that "the functional need for attached gingiva around implants has not been established but its aesthetic value has been widely accepted.(Mehta and Lim 2010)

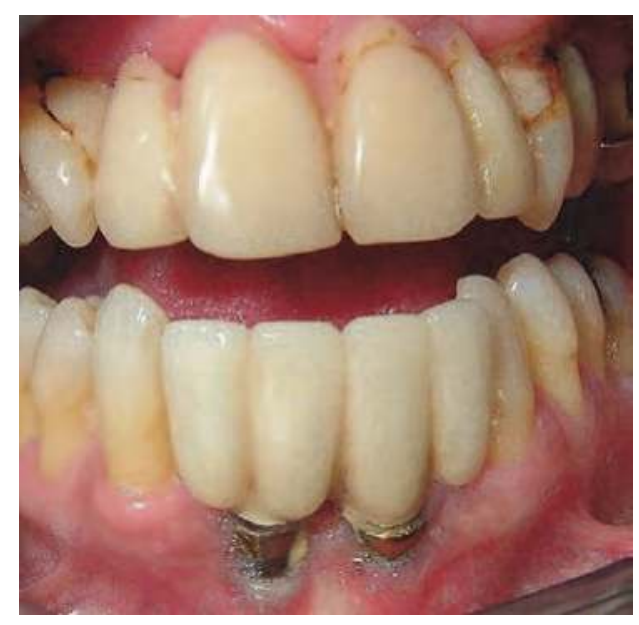

Fig. 1. Common situation encountered where poor oral hygiene resulted in the breakdown of mucosal tissue around implant/abutment.

\subsection{Peri-implant tissue thickness and biological width}

The dimension of the soft tissue attachment to the implant/abutment surface was considered important for the maintenance of peri-implant health and for the overall aesthetics of the final restoration. For many years, the concept of a biological width was used to explain the clinical observation of a constant dimension of dento-gingival junction around teeth and dental restorations(Gargiulo, Wentz et al. 1961). Berglundh and Lindhe demonstrated that in a dog model, similar constancy of gingival dimension was observed in 
peri-implant tissue as well(Berglundh and Lindhe 1996). In an elegant experiment, the authors showed that by surgically reducing the thickness of the gingival flap prior to suturing, a corresponding crestal bone remodelling will subsequently occur allowing for the re-establishment of the "biological width" of the peri-implant soft tissue to its original dimension at the expense of reduced crestal bone height. This situation is analogous to the surgical procedure used in " crown lengthening" on natural teeth -an attempt to surgically position the gingival margin more apically and thus allow for an increased restorative space either for aesthetic reasons or for increasing the ferrule of coronal structure to improve on the retention of the planned restoration. This finding had great clinical implications because it provided a rationale for the careful placement of the soft tissue at the "correct" and stable position for the final peri-implant tissue finish. It also explained, at least in part, why it was important to maintain the alveolar crest in order to support the over-lying soft tissue.

Further studies comparing one-stage and two-stage procedures (submerged versus nonsubmerged) (Buser, Weber et al. 1992; Weber, Buser et al. 1996), loaded or unloaded nonsubmerged implants (Cochran, Hermann et al. 1997), different implant systems (Abrahamsson, Berglundh et al. 1996), different material surfaces (Arvidson, Fartash et al. 1996) and different level of placement of the implant-abutment junction (micro-gap) (Hermann, Cochran et al. 2001) failed to demonstrate any difference in peri-implant tissue dimension (thickness) under these variable conditions. Taken together, these observations confirmed that the concept of biological width of the gingiva around natural teeth was equally applicable to peri-implant soft tissues. These data further validated the need for a suitable implant design that allow for optimal soft-tissue attachment in order to achieve good soft tissue stability. It also provided a useful reminder to the clinicians that careful attention should be paid to the soft tissue finish when planning implant treatment cases.

\subsection{The 3-dimensional relationship between alveolar bone and the overlying gingiva}

If the biological width concept does indeed accurately describe the natural phenomenon of the inter-dependency of these two tissues (alveolar bone and gingiva), a corollary of the biological width concept would then state that a fixed thickness of gingiva will follow the position and contour of the underlying alveolar bone crest. Indeed, clinical observation of the remodelling of alveolar ridge, such as that following tooth extraction, does appear to confirm this concept. It is therefore important that when planning an implant placement in an extraction site, the dentist is able to predict and anticipate where the remodelled bone will be in future, and hence where the gingival margin will lie in relation to the dental restoration supported by the implant(Khoury and Happe 2000; Grunder, Gracis et al. 2005). Unfortunately, it is not always possible to accurately predict the extent of bone resorption during the remodelling process. In an animal model, Araujo and colleagues described in detail the pattern of alveolar remodelling following tooth extraction(Araujo and Lindhe 2005) and following implant placement(Araújo, Sukekava et al. 2005). Cumulative clinical experience suggests that bulky alveolar process (thick biotype) shows greater dimensional stability during remodelling compared with less bulky alveolar process (thin biotype). It was theorised that in thick biotype, the presence of lamina bone adjacent to the outer cortical plate of the alveolus provides the foundation for metabolic support of the cortical bone, and hence its stability and sustainability. In thin biotype, where the lamina bone is scarce or absent, the cortical bone is subjected to rapid resorption by osteoclastic type cells present in the healing bone wound (such as an extraction socket). Although the relationship between bone repair and the host genotype is not entirely clear at the moment, the above theory does 
go some way in explaining the clinical observation in alveolar ridge remodelling following tooth extraction.

\subsection{Does the presence of implant help to preserve bone?}

The placement of a dental implant in a fresh extraction socket (immediate placement) does not appear to interrupt the healing process of the socket wound(Botticelli, Berglundh et al. 2004; Araújo, Sukekava et al. 2005; Araújo, Sukekava et al. 2006; Araujo, Wennstrom et al. 2006). It is therefore, possible to extract a tooth (or teeth) and place dental implants in the same visit. The proponents and supporters of this clinical protocol of immediate implant placement have argued that the presence of a dental implant helps to preserve the height of the surrounding bone. Animal studies and human clinical studies have not yield evidence to support this notion(Wyatt and Zarb 2002; Covani, Cornelini et al. 2003; Covani, Bortolaia et al. 2004). In a single-tooth implant situation, the stability of the interseptal bone appears to be influenced by the periodontal ligament level of the adjacent teeth, rather than the level of bone-titanium interface. The labial bone plate is not supported by any neighbouring teeth and therefore can undergo rapid resorption and remodelling once its "host tooth" has been extracted. In patients with thin biotype, a rapid remodelling and disappearance of the labial bone crest can often result in disastrous clinical outcome where implants were placed immediately into extraction sockets. It is now clear that this clinical technique can yield unpredictable results and therefore should be attempted only with great caution. Drawing from our current understanding of the sequence of biological events in bone repair after tooth extraction, and in particular, the remodelling of the labial bone plate, it is not surprising to find that many immediately placed implants in the aesthetic zone ended up with disastrous results.

\section{Managing the soft tissue around implants}

\subsection{Implant placement in the "correct" anatomical position}

Based on our understanding of the constancy of gingival tissue thickness overlying alveolar bone surrounding teeth or dental implants and our knowledge of the healing behaviour of peri-implant soft tissue after wounding, it is possible to estimate the "final position" of the healed tissue around restorations placed on dental implants. The ability of the clinician to accurately forecast the final position of the healed tissue will underpin the long term success of any implant restoration (figures $2 \mathrm{a}$ and $2 \mathrm{~b}$ ). On the other hand, unrealistic expectation of reconstituting lost tissues by placing gingival tissue a greater distance from the underlying alveolar bone, such as in the case when the implant is placed apically relative to the adjacent teeth, will inevitably lead to future complications. This scenario can arise when the implanted site has been compromised by previous extraction or exposed to infection of long standing. In these situations, bone augmentation should be considered as part of the treatment plan if a stable soft tissue result is to be achieved. (Figure $3 \mathrm{a}$ and $\mathrm{b}$ )

\subsection{Important considerations during case planning}

During the treatment planning stage of dental implant treatment, special attention should be given to assessing the proposed implant site as well as other systemic factors that may influence the performance and survival of the implant. Implant site assessment should include: 


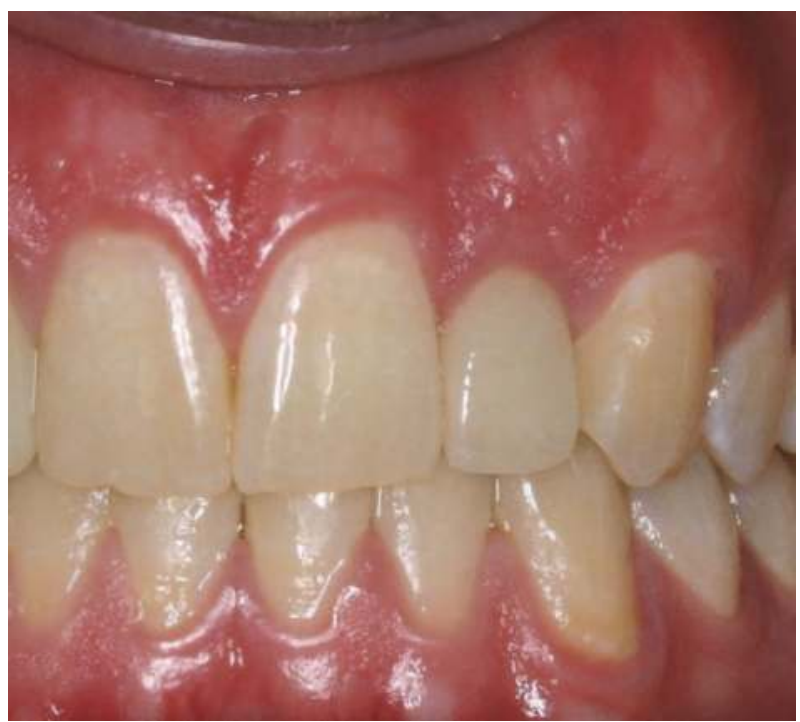

Fig. 2a. Stable gingival position with adequate bone support

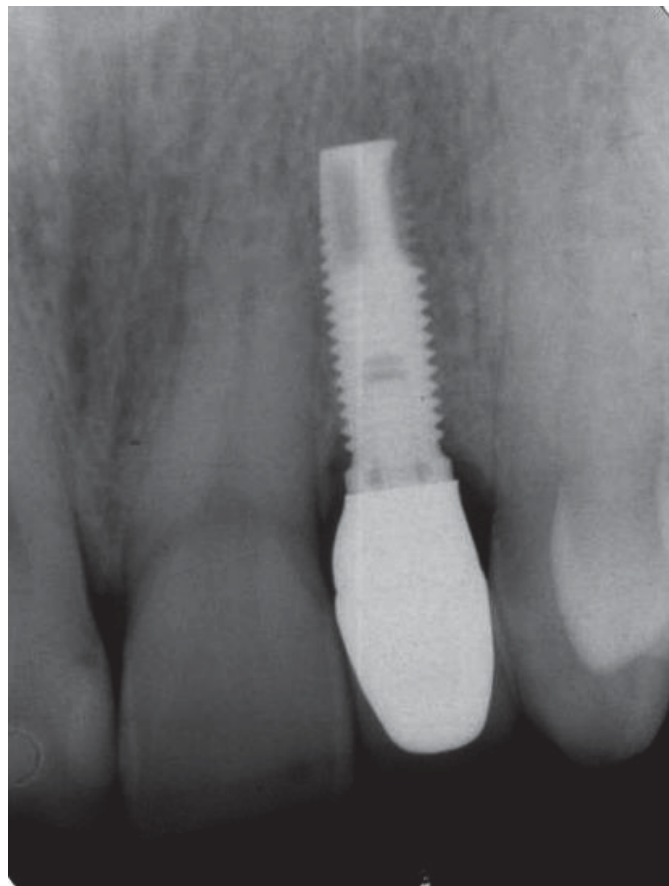

Fig. 2b. Radiograph showing the position of the dental implant relative to the adjacent teeth 


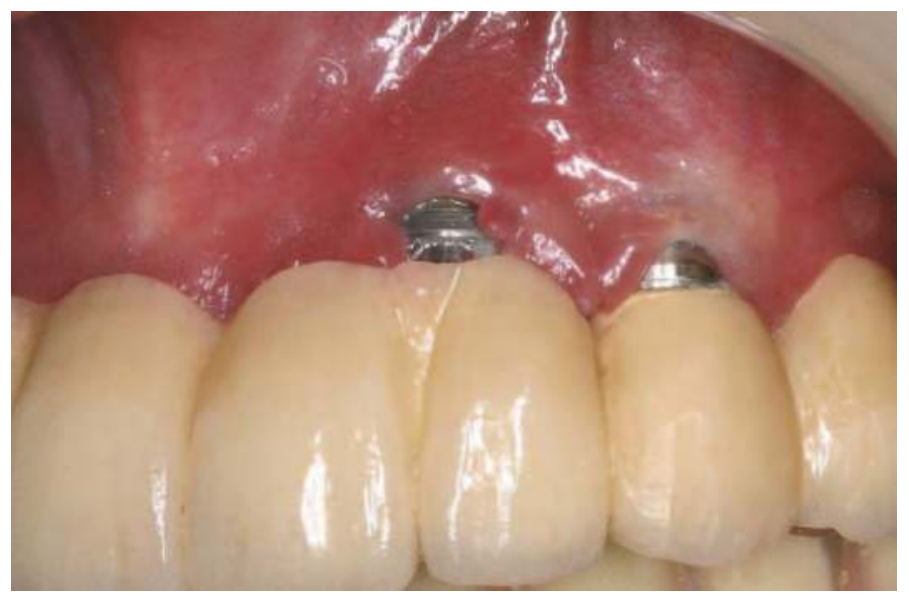

Fig. 3a. Gingival recession due to missing bone underneath

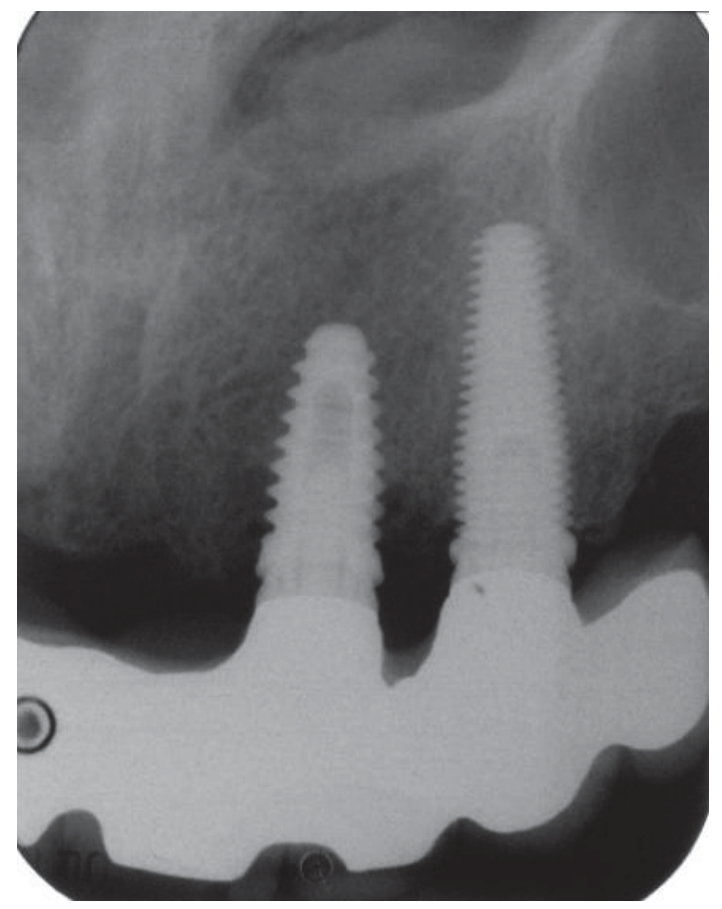

Fig. 3b. Radiograph of the same patient in figure $2 a$ 
- Checking for pre-existing pathology - such as chronic and persistent granulomatous lesions associated with the extracted tooth, non-healing abscesses, dentigerous cysts etc

- Evaluating the anatomical defect at the site - such as extreme ridge resorption following extraction

- Determining the biotype of the patient especially when the treatment site is in the aesthetic zone

- Deciding on the appropriate time for the implant placement in relation to the time of extraction

The systemic factors that require special attention are the important "risk factors" associated with implant complications and failures such as past history of periodontal disease and a smoking habit.

\subsection{Surgical techniques}

There had been numerous publications in the dental literature describing various surgical techniques suitable for augmenting the implant sites. Most of these procedures aim at adding bulk and thickness to the soft tissue surrounding dental implant restorations. Others aim at increasing the width of the attached gingival band surrounding these restorations. The interchangeable use of the term "keratinized gingiva" and "attached gingiva " had led to some confusion among dentists. From the current data available, there is no conclusive evidence to suggest that keratinized gingiva is essential in maintaining health of the periimplant soft tissue(Carmichael, Apse et al. 1989). Paradoxically, most clinicians comment that attached gingiva around implant restorations will provide longer term stability and comfort and acceptance by the patient(Cairo, Pagliaro et al. 2008; Schrott, Jimenez et al. 2009). It may well be that the "immobilisation" of the soft tissue band is important for oral hygiene maintenance and stability and health of the tissue, and not so much the type of epithelial cells covering this soft tissue band.

By far the most popular surgical technique for augmenting the soft tissue at implant sites utilises autogenous graft from the same patient either in the form of subepithelial gingival graft (connective tissue graft)(Langer and Langer 1985) or gingival graft (free gingival graft)(Miller Jr 1982; Miller Jr 1985; Miller Jr 1993). These grafts are usually harvested from the palatal vault of the same patient and transferred to the recipient site. In the aesthetic zone it is usually necessary to provide a band of keratinized gingiva in order to harmonise with those surrounding the adjacent natural teeth. Under this circumstance, a connective tissue graft with a collar of epithelium attached will achieve the desired result. (Figure 4)

In a systemic review of surgical procedures for soft tissue augmentation, all autogenous tissue graft procedures were found to be effective in increasing tissue volume. No one technique was found to be superior to others (Thoma, Beni et al. 2009). It would therefore appear that treatment success is not a function of the choice of a surgical technique and the choice of a specific surgical technique is not as important as the adherence to sound biologic principles (such as those listed earlier in this chapter) if good clinical outcome is to be achieved.

\section{Future research}

The advancement in implant dentistry in the past 20 years has been rapid. Studies in the biological sciences have provided us with a clearer understanding of the wound healing events following tooth extraction as well as following dental implant placement in the 


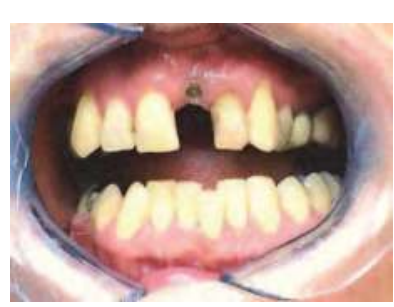

(a)

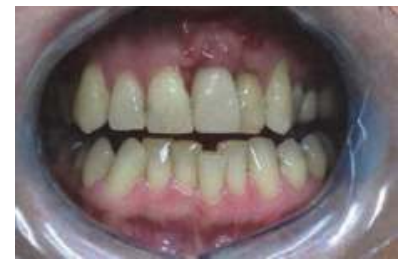

(d)

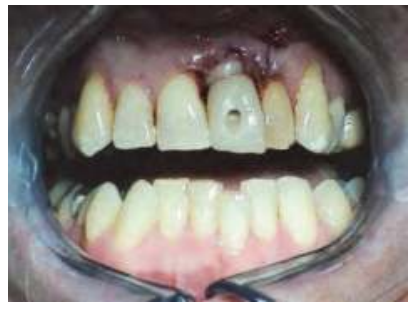

(b)

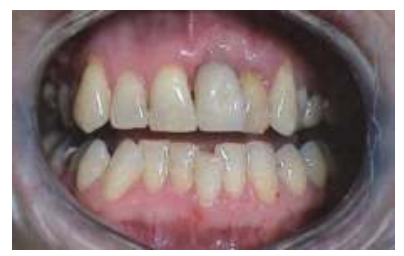

(e)

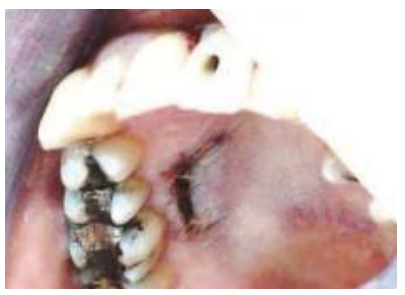

(c)

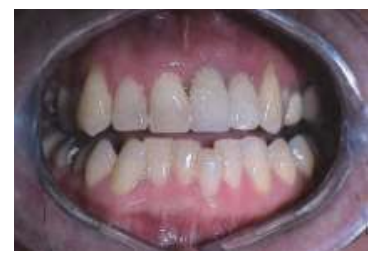

(f)

Fig. 4. Connective tissue grafting was used to repair tissue deficit as a result of implant malpositioning. a) positioning of dental implant (too labially placed and too palatally angled) and showing a lack of labial gingiva; b) connective tissue graft placed at the time when the temporary crown was issued; c) donor site on the palatal vault where the graft tissue was harvested from; d) healing at 1 week; e) at 1 month and f) at 1 year.

human jaws. This in turn drove the implant industry to seek to improve on the surface characteristics of implants to enhance early healing. The introduction of the "roughened" surface did show reduced time for osseointegration and establish clinical stability to enable earlier loading. However, the concept of immediate implant placement after extraction had not demonstrated universal success mainly due to bone remodelling complications. The research in "biological factors" to enhance the speed and quality of osseointegration has shown some promise and is continuing. The release into the market place of two dental implants with "bioactive" surface has not met with resounding success.(Cooper, Zhou et al. 2006; Schwarz, Herten et al. 2007; Junker, Dimakis et al. 2009). Clearly, the industry-driven effort in improving the engineering aspect of implant development will continue at a rapid pace. On the other hand, we have not made as much progress in the biological advances in the clinical science of implant therapy. We have used biomechanical refinement on the engineering of implant to cope with "softer" bone, such as implant thread design, implant body design, and implant surface design. To date, we have not explored the possibility of modifying the bony trabecular pattern and density in order to change a "type 4 bone" to a "type 3 bone", or from a "type 3 bone" to a "type 2 bone" etc. Equally important, we have not harnessed the adaptive property of living bone to respond to the presence of a loaded dental implant nor have we attempted to influence the metabolic activity of bone tissue to ensure that the dynamics of the osseointegration interface is maintained throughout the life of the implant. Last, but not the least, we have not paid enough attention to the complication of peri-implantitis - how to prevent it, how to treat it and how to repair the defect it creates. Future research in these two important areas of biology and clinical practice is urgently needed. 


\section{References}

Abrahamsson, I., T. Berglundh, et al. (1999). "Peri-implant tissues at submerged and nonsubmerged titanium implants." Journal of clinical periodontology 26(9): 600-607.

Abrahamsson, I., T. Berglundh, et al. (1996). "The peri implant hard and soft tissues at different implant systems. A comparative study in the dog." Clinical Oral Implants Research 7(3): 212-219.

Abrahamsson, I., N. Zitzmann, et al. (2002). "The mucosal attachment to titanium implants with different surface characteristics: an experimental study in dogs." Journal of clinical periodontology 29(5): 448-455.

Araujo, M. G. and J. Lindhe (2005). "Dimensional ridge alterations following tooth extraction. An experimental study in the dog." Journal of clinical periodontology 32(2): 212-218.

Araújo, M. G., F. Sukekava, et al. (2005). "Ridge alterations following implant placement in fresh extraction sockets: an experimental study in the dog." Journal of clinical periodontology 32(6): 645-652.

Araújo, M. G., F. Sukekava, et al. (2006). "Tissue modeling following implant placement in fresh extraction sockets." Clinical Oral Implants Research 17(6): 615-624.

Araujo, M. G., J. L. Wennstrom, et al. (2006). "Modeling of the buccal and lingual bone walls of fresh extraction sites following implant installation." Clinical Oral Implants Research 17(6): 606.

Arvidson, K., B. Fartash, et al. (1996). "Histological characteristics of peri implant mucosa around Brånemark and single crystal sapphire implants." Clinical Oral Implants Research 7(1): 1-10.

Berglundh, T. and J. Lindhe (1996). "Dimension of the periimplant mucosa." Journal of clinical periodontology 23(10): 971-973.

Berglundh, T., J. Lindhe, et al. (1991). "The soft tissue barrier at implants and teeth." Clinical Oral Implants Research 2(2): 81-90.

Botticelli, D., T. Berglundh, et al. (2004). "Hard tissue alterations following immediate implant placement in extraction sites." Journal of clinical periodontology 31(10): 820-828.

Brånemark, P. I., B. Svensson, et al. (1995). "Ten year survival rates of fixed prostheses on four or six implants ad modum Brånemark in full edentulism." Clinical Oral Implants Research 6(4): 227-231.

Buser, D., R. Mericske stern, et al. (1997). "Long term evaluation of non submerged ITI implants. Part 1: 8 year life table analysis of a prospective multi center study with 2359 implants." Clinical Oral Implants Research 8(3): 161-172.

Buser, D., H. Weber, et al. (1992). "Soft tissue reactions to non-submerged unloaded titanium implants in beagle dogs." Journal of Periodontology 63(3): 225.

Cairo, F., U. Pagliaro, et al. (2008). "Soft tissue management at implant sites." Journal of clinical periodontology 35: 163-167.

Carmichael, R., P. Apse, et al. (1989). "Biological, microbiological and clinical aspects of the peri-implant mucosa." The Branemark Osseointegrated implant. Chicago: Quintaessence. 
Cochran, D. L., J. S. Hermann, et al. (1997). "Biologic width around titanium implants. A histometric analysis of the implanto-gingival junction around unloaded and loaded nonsubmerged implants in the canine mandible." Journal of Periodontology 68(2): 186.

Çomut, A. A., H. P. Weber, et al. (2001). "Connective tissue orientation around dental implants in a canine model." Clinical Oral Implants Research 12(5): 433-440.

Cooper, L. F., Y. Zhou, et al. (2006). "Fluoride modification effects on osteoblast behavior and bone formation at $\mathrm{TiO} 2$ grit-blasted cp titanium endosseous implants." Biomaterials 27(6): 926-936.

Cosyn, J., M. M. Sabzevar, et al. (2007). "Commentary: Two-Piece Implants With Turned Versus Microtextured Collars." Journal of Periodontology 78(9): 1657-1663.

Covani, U., C. Bortolaia, et al. (2004). "Bucco-lingual crestal bone changes after immediate and delayed implant placement." Journal of Periodontology 75(12): 1605-1612.

Covani, U., R. Cornelini, et al. (2003). "Bucco-lingual bone remodeling around implants placed into immediate extraction sockets: A case series." Journal of Periodontology 74(2): 268-273.

Esposito, M., L. Murray-Curtis, et al. (2007). "Interventions for replacing missing teeth: different types of dental implants." Cochrane database of systematic reviews (Online)(4): CD003815.

Garant, P. R. and M. I. Cho (1979). "Autoradiographic evidence of the coordination of the genesis of Sharpey's fibers with new bone formation in the periodontium of the mouse." Journal of Periodontal Research 14(2): 107-114.

Gargiulo, A. W., F. M. Wentz, et al. (1961). "Dimensions and relations of the dentogingival junction in humans." J Periodontol 32(3): 261-267.

Grunder, U., S. Gracis, et al. (2005). "Influence of the 3D bone-to-implant relationship on esthetics." Restorative Dent 25: 113-119.

Hermann, J. S., D. L. Cochran, et al. (2001). "Biologic Width around one and two piece titanium implants." Clinical Oral Implants Research 12(6): 559-571.

Jemt, T., J. Chai, et al. "A 5-year prospective multicenter follow-up report on overdentures supported by osseointegrated implants." The International journal of oral \& maxillofacial implants 11(3): 291.

Junker, R., A. Dimakis, et al. (2009). "Effects of implant surface coatings and composition on bone integration: a systematic review." Clinical Oral Implants Research 20: 185-206.

Khoury, F. and A. Happe (2000). "Soft tissue management in oral implantology: a review of surgical techniques for shaping an esthetic and functional peri-implant soft tissue structure." Quintessence international (Berlin, Germany: 1985) 31(7): 483.

Krygier, G., P. Glick, et al. "To minimize complications, is it essential that implant abutments be surrounded by keratinized tissue?" The International journal of oral \& maxillofacial implants 12(1): 127.

Langer, B. and L. Langer (1985). "Subepithelial connective tissue graft technique for root coverage." Journal of Periodontology 56(12): 715-720. 
Lindhe, J. and J. Meyle (2008). "Peri implant diseases: Consensus Report of the Sixth European Workshop on Periodontology." Journal of clinical periodontology 35: 282-285.

Lindquist, L., G. Carlsson, et al. (1996). "A prospective 15 year follow up study of mandibular fixed prostheses supported by osseointegrated implants. Clinical results and marginal bone loss." Clinical Oral Implants Research 7(4): 329-336.

Mehta, P. and L. P. Lim (2010). "The width of the attached gingiva--Much ado about nothing?" Journal of dentistry 38(7): 517-525.

Mericske-Stern, R. (1998). "Treatment outcomes with implant-supported overdentures: clinical considerations." The Journal of Prosthetic Dentistry 79(1): 66-73.

Miller Jr, P. (1982). "Root coverage using a free soft tissue autograft following citric acid application. Part 1: Technique." The International journal of periodontics \& restorative dentistry 2(1): 65 .

Miller Jr, P. (1985). "Root coverage using the free soft tissue autograft following citric acid application. III. A successful and predictable procedure in areas of deep-wide recession." The International journal of periodontics \& restorative dentistry 5(2): 14.

Miller Jr, P. (1993). "Root coverage grafting for regeneration and aesthetics." Periodontology $20001(1): 118$.

Piattelli, A., A. Scarano, et al. (1997). "Histologic aspects of the bone and soft tissues surrounding three titanium non-submerged plasma-sprayed implants retrieved at autopsy: a case report." Journal of Periodontology 68(7): 694.

Rocci, A., M. Martignoni, et al. (2003). "Histology of retrieved immediately and early loaded oxidized implants: light microscopic observations after 5 to 9 months of loading in the posterior mandible." Clinical implant dentistry and related research 5: 88-98.

Roos Jansåker, A. M., C. Lindahl, et al. (2006). "Nine to fourteen year follow up of implant treatment. Part II: presence of peri implant lesions." Journal of clinical periodontology 33(4): 290-295.

Ruggeri, A., M. Franchi, et al. (1994). "Histologic Ultrastructural Findings of Gingival Circular Ligament Surrounding Osseointegrated Nonsubmerged Loaded Titanium Implants." International Journal of Oral and Maxillofacial Implants 9(6): 636-643.

Schrott, A. R., M. Jimenez, et al. (2009). "Five year evaluation of the influence of keratinized mucosa on peri implant soft tissue health and stability around implants supporting full arch mandibular fixed prostheses." Clinical Oral Implants Research 20(10): 1170-1177.

Schupbach, P. and R. Glauser (2007). "The defense architecture of the human periimplant mucosa: a histological study." The Journal of Prosthetic Dentistry 97(6): S15-S25.

Schwarz, F., M. Herten, et al. (2007). "Bone regeneration in dehiscence type defects at chemically modified (SLActive $\left.{ }^{\circledR}\right)$ and conventional SLA titanium implants: a pilot study in dogs." Journal of clinical periodontology 34(1): 78-86.

Thoma, D. S., G. I. Beni, et al. (2009). "A systematic review assessing soft tissue augmentation techniques." Clinical Oral Implants Research 20: 146-165. 
Weber, H., D. Buser, et al. (1996). "Comparison of healed tissues adjacent to submerged and non submerged unloaded titanium dental implants. A histometric study in beagle dogs." Clinical Oral Implants Research 7(1): 11-19.

Wyatt, C. C. L. and G. A. Zarb (2002). "Bone level changes proximal to oral implants supporting fixed partial prostheses." Clinical Oral Implants Research 13(2): 162168. 


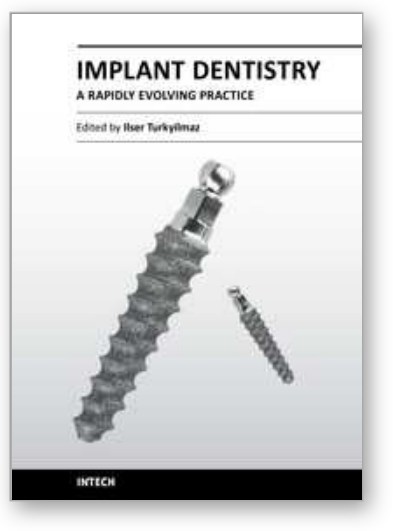

\author{
Implant Dentistry - A Rapidly Evolving Practice \\ Edited by Prof. Ilser Turkyilmaz
}

ISBN 978-953-307-658-4

Hard cover, 544 pages

Publisher InTech

Published online 29, August, 2011

Published in print edition August, 2011

Implant dentistry has come a long way since Dr. Branemark introduced the osseointegration concept with endosseous implants. The use of dental implants has increased exponentially in the last three decades. As implant treatment became more predictable, the benefits of therapy became evident. The demand for dental implants has fueled a rapid expansion of the market. Presently, general dentists and a variety of specialists offer implants as a solution to partial and complete edentulism. Implant dentistry continues to evolve and expand with the development of new surgical and prosthodontic techniques. The aim of Implant Dentistry - A Rapidly Evolving Practice, is to provide a comtemporary clinic resource for dentists who want to replace missing teeth with dental implants. It is a text that relates one chapter to every other chapter and integrates common threads among science, clinical experience and future concepts. This book consists of 23 chapters divided into five sections. We believe that, Implant Dentistry: A Rapidly Evolving Practice, will be a valuable source for dental students, post-graduate residents, general dentists and specialists who want to know more about dental implants.

\title{
How to reference
}

In order to correctly reference this scholarly work, feel free to copy and paste the following:

Yeung Stephen C H (2011). Soft Tissue Biology and Management in Implant Dentistry, Implant Dentistry - A Rapidly Evolving Practice, Prof. Ilser Turkyilmaz (Ed.), ISBN: 978-953-307-658-4, InTech, Available from: http://www.intechopen.com/books/implant-dentistry-a-rapidly-evolving-practice/soft-tissue-biology-andmanagement-in-implant-dentistry

\section{INTECH}

open science | open minds

\section{InTech Europe}

University Campus STeP Ri

Slavka Krautzeka 83/A

51000 Rijeka, Croatia

Phone: +385 (51) 770447

Fax: +385 (51) 686166

www.intechopen.com

\section{InTech China}

Unit 405, Office Block, Hotel Equatorial Shanghai

No.65, Yan An Road (West), Shanghai, 200040, China 中国上海市延安西路65号上海国际贵都大饭店办公楼405单元

Phone: +86-21-62489820

Fax: +86-21-62489821 
(C) 2011 The Author(s). Licensee IntechOpen. This chapter is distributed under the terms of the Creative Commons Attribution-NonCommercialShareAlike-3.0 License, which permits use, distribution and reproduction for non-commercial purposes, provided the original is properly cited and derivative works building on this content are distributed under the same license. 